\title{
Physiological and genetic basis for variation in migratory behavior in the three-spined stickleback, Gasterosteus aculeatus
}

\author{
Jun Kitano • Asano Ishikawa • Manabu Kume • \\ Seiichi Mori
}

Received: 21 March 2012/Revised: 14 May 2012/Accepted: 15 May 2012/Published online: 9 June 2012

(C) The Ichthyological Society of Japan 2012

\begin{abstract}
Closely related species of fish often exhibit different migration patterns. Even within species, anadromous and resident populations can be found in a diverse number of taxa. Although several environmental factors that regulate behavioral and physiological changes associated with fish migration have been identified, the genetic mechanisms underlying the variation in the ability to respond to these environmental cues in fishes that show different migratory behaviors are not well known. The three-spined stickleback Gasterosteus aculeatus (Linnaeus 1758) is a good model system for elucidation of the genetic basis for variation in migratory behaviors and other physiological changes associated with migration. First, the three-spined stickleback exhibits great inter-population variation in migration patterns. Second, genetic and genomic tools are now available for studying this species. In the present study, variation in the migration patterns among G. aculeatus populations and the recent progress in our understanding of the genetic and physiological basis for variation in traits important for G. aculeatus migration are reviewed.
\end{abstract}

Keywords Gasterosteus aculeatus · Anadromy · Partial migration · Genomics · Hormone

\footnotetext{
J. Kitano $(\bowtie) \cdot$ A. Ishikawa

Ecological Genetic Laboratory and PRESTO, Center for Frontier Research, National Institute of Genetics, Yata 1111, Mishima, Shizuoka 411-8540, Japan

e-mail: jkitano@lab.nig.ac.jp

M. Kume $\cdot$ S. Mori

Biological Laboratory, Gifu-keizai University, Kitakata-cho 5-50, Ogaki, Gifu 503-8550, Japan
}

\section{Introduction}

Fishes exhibit great diversity in their migration patterns (McKeown 1984; McDowall 1988; Dodson 1997; Hendry and Stearns 2004). Migration has both advantages and disadvantages. Advantages include optimal foraging, avoidance of unfavorable environments, and increased reproductive output, while disadvantages include energetic costs, osmoregulatory shocks, and increased predation (McKeown 1984; McDowall 1988; Dodson 1997; Hendry and Stearns 2004). Optimal trade-offs between benefits and costs may differ between environments and can lead to diversity in migratory behaviors. For example, anadromy is more common in temperate regions, while catadromy is more common in tropical regions (Gross et al. 1988). This pattern can be explained by the difference in productivity between freshwater and marine environments, with oceans being more productive than freshwater environments in temperate regions and vice versa in tropical regions. When there are two or more optimal strategies, alternative life histories with different migration patterns can evolve within populations (Gross 1985; Chapman et al. 2011). Compared to the theoretical and ecological studies on the driving forces of diverse migratory behaviors (Gross 1985, 1997; Dodson 1997; Hendry and Stearns 2004), surprisingly little is known about the genetic mechanisms underlying variation in migratory behaviors.

Diadromous migration comprises multiple behavioral traits (Hoar 1958, 1976; McKeown 1984; Quinn 2005), including salinity preference (Baggerman 1957; Houston 1957; McInerney 1964; Iwata et al. 1986), response to water current (rheotaxis) (Hensleigh and Hendry 1998), response to light (Hoar et al. 1957), response to overhead cover (Kemp et al. 2005), and magnetoreception (Quinn 2005). Divergence in some of these behavioral traits has 
been observed among closely related species of several taxa, including Oncorhynchus (Hoar et al. 1957; Houston 1957; Hoar 1958; Taylor and McPhail 1985; Hutchinson and Iwata 1997) and Gasterosteidae (Audet et al. 1985). These behavioral traits are usually regulated by environmental factors, such as photoperiod and temperature, internal factors, such as hormones, and their interactions (McKeown 1984; Iwata 1995; McCormick 2001; Ramenofsky and Wingfield 2007). Therefore, elucidation of the genetic mechanisms by which the endocrine system of migratory and non-migratory species responds differently to environmental cues is indispensable for a better understanding of the genetic and molecular mechanisms underlying the variation in diadromous migration.

The three-spined sticklebacks Gasterosteus aculeatus (Linnaeus 1758) provides a good model system for understanding the genetic mechanisms underlying variation in migratory behaviors (Fig. 1). First, tremendous diversification of G. aculeatus in the last few million years has resulted in the evolution of phenotypically and ecologically divergent forms, which can often exhibit different migration patterns (Wootton 1976, 1984; Bell and Foster 1994; McKinnon and Rundle 2002; Östlund-Nilsson et al. 2007). Second, genetic and genomic tools, such as linkage maps, whole-genome sequencing, microarrays, single-nucleotide polymorphism (SNP) arrays, restriction-site-associated DNA sequencing (sequenced RAD), and transgenics are available for studying G. aculeatus (Hosemann et al. 2004; Peichel 2005; Cresko et al. 2006; Kingsley and Peichel 2007; Geoghegan et al. 2008; Kitano et al. 2009, 2010; Leder et al. 2009; Chan et al. 2010; Hohenlohe et al. 2010; Jones et al. 2012a, b). Recent genetic studies have elucidated molecular mechanisms underlying morphological divergence between anadromous and freshwater-resident forms of G. aculeatus (Shapiro et al. 2004; Colosimo et al. 2005; Miller et al. 2007; Chan et al. 2010). However, little is known about the genetic and molecular mechanisms underlying variation in behavioral and physiological traits involved in fish migration or the photoperiodic response of the endocrinological system in G. aculeatus. This study reviews variation in migratory behaviors among and within G. aculeatus populations and recent progress in the genetic and genomic studies on the physiological divergence between anadromous and freshwater-resident G. aculeatus.

\section{Diversity of migration in Gasterosteus aculeatus}

Substantial variation in migration patterns exist among Gasterosteus aculeatus populations. First, the G. aculeatus species complex includes both anadromous and freshwaterresident forms of G. aculeatus (Bell and Foster 1994; McKinnon and Rundle 2002). The ancestral forms of

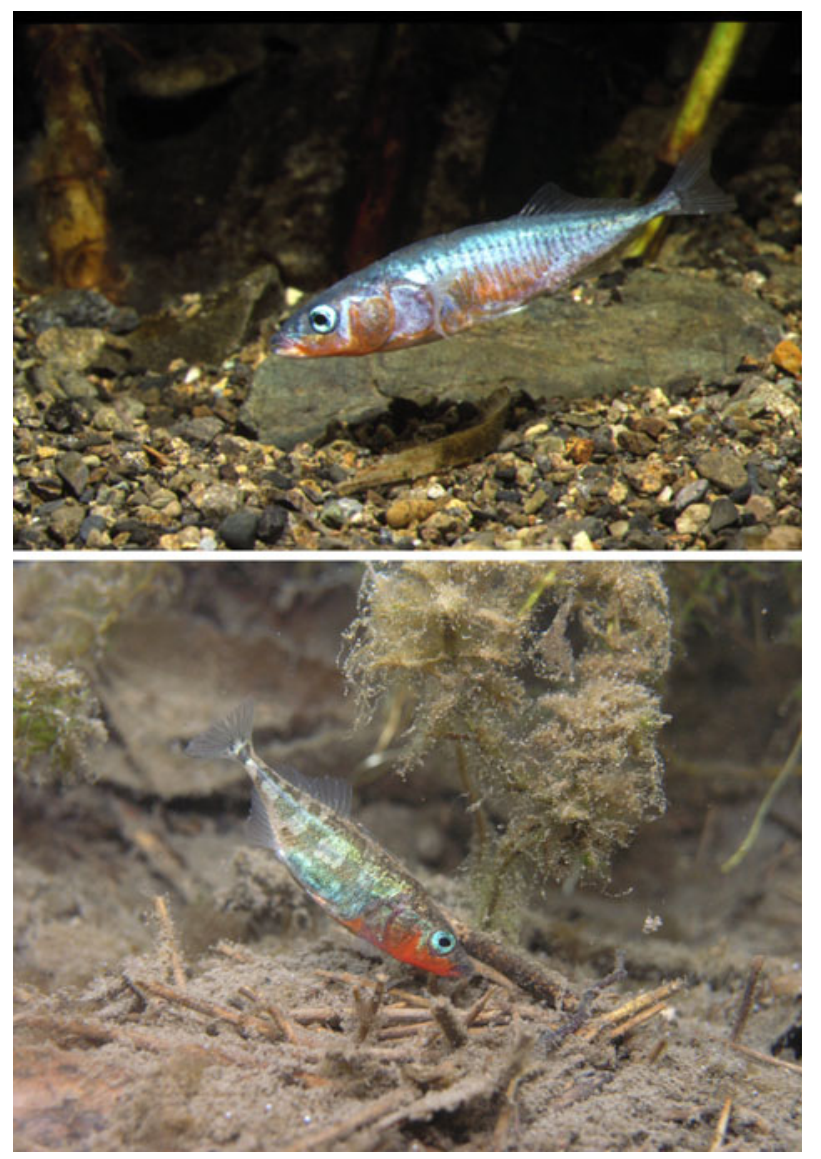

Fig. 1 Pictures of anadromous (upper panel) and stream-resident forms (lower panel) of Gasterosteus aculeatus

G. aculeatus are considered anadromous, whereas freshwater-resident forms have evolved independently from the anadromous forms in multiple lineages (Haglund et al. 1992; Orti et al. 1994; Taylor and McPhail 1999, 2000; McKinnon et al. 2004; Colosimo et al. 2005). The anadromous forms of G. aculeatus usually migrate to freshwater or estuaries in spring (Table 1), while juveniles migrate to the sea in fall (Table 2), although there are substantial variation in the timing of migration (Tables 1,2$)$. Interestingly, the timing of spawning migration tends to be earlier in populations at lower latitudes than in populations at higher latitudes (Table 1). Although we did not see any clear latitudinal trends of the timing of juvenile migration, the Japan Sea forms likely descend earlier than the Pacific Ocean forms in Japan (Kume and Kitamura 2003; Table 2). Variation also exists in the offshore distance during migration among anadromous G. aculeatus populations (Table 3), but the precise migratory routes in marine environments have not been systematically investigated.

Freshwater-resident forms are sometimes completely landlocked and never come in contact with the anadromous forms (Fig. 2a). In other cases, habitats of freshwater-resident forms are connected to the sea; when anadromous 
Table 1 Variation in the timing of upstream migration between anadromous populations

\begin{tabular}{llll}
\hline Population & Month & Latitude & References \\
\hline Japan Sea form from Nagata River, Japan & Apr. & 34 & Amaoka and Haruta (1972) \\
Japan Sea form from Mimi River, Japan & Mar.-Apr. & 35.6 & Mori, pers. obs. \\
Japan Sea form from Kuriyama River, Japan & Feb.-Apr. & 36 & Kume (2008) \\
Japan Sea form from Kahoku Lagoon, Japan & Mar.-Apr. & 36.6 & Mori (1987) \\
Japan Sea form from Niigata, Japan & Feb.-Mar. & 38 & Ikeda (1937) \\
Japan Sea form from Mogami River, Japan & Mar.-May & 39 & Mori, pers. obs. \\
Japan Sea form from Oga Peninsula, Japan & Apr.-May & 40 & Mori, pers. obs. \\
Japan Sea form from Lake Ogawara, Japan & Apr.-May & 40.8 & Katayama et al. (2000) \\
Pacific Ocean form from Akkeshi, Japan & Apr.-May & 43 & Kume and Kitamura (2003), Kume et al. (2005) \\
Japan Sea form from Akkeshi, Japan & Apr.-May & 43 & Kume and Kitamura (2003), Kume et al. (2005) \\
Little Campbell River in British Columbia, Canada & June-July & 49 & Hagen (1967) \\
Långskär and Vindskär Bays in Baltic Sea, Finland & May-July & 60 & Candolin and Voigt (2003) \\
\hline
\end{tabular}

Table 2 Variation in the timing of seaward migration between anadromous populations

\begin{tabular}{llll}
\hline Population & Month & Latitude & References \\
\hline Japan Sea form from Lake Shibayama, Japan & June-July & 36.3 & Mori, pers. obs. \\
Japan Sea form from Lake Kahoku, Japan & June-July & 36.6 & Mori, pers. obs. \\
Navarro River in California, USA & Sep. & 39 & Snyder and Dingle (1989) \\
Japan Sea form from Lake Ogawara, Japan & July & 40.8 & Katayama et al. (2000) \\
Japan Sea form from Akkeshi, Japan & July-Aug. & 43 & Kume and Kitamura (2003) \\
Japan Sea form from Biwase, Japan & July-Aug. & 43 & Kume and Mori (2009) \\
Pacific Ocean form from Akkeshi, Japan & Nov.-Dec. & 43 & Kume and Kitamura (2003), Kitamura et al. (2006) \\
Duwamish estuary, Washington, USA & Sep. & 47.5 & Kitano, pers. obs. \\
Shilshole Bay, Washington, USA & Sep. & 47.6 & Kitano, pers. obs. \\
Island of Tholen and Yerseke, The Netherlands & July & 51.5 & van Mullen and van der Vlugt (1964) \\
England & Oct. & 52 & Craig-Bennett (1931) \\
Northern Germany & Sep. & 53.5 & Leiner (1930) \\
\hline
\end{tabular}

Table 3 Records of Gasterosteus aculeatus caught at sea

\begin{tabular}{lllll}
\hline Collection site & $\begin{array}{l}\text { Distance from the nearest } \\
\text { land }(\mathrm{km})\end{array}$ & Season & Depth $(\mathrm{m})$ & References \\
\hline North Atlantic Ocean & $145-160$ & Dec.-Jan. & $221-232$ & Jones and John (1978) \\
North Pacific Ocean & $<945$ & May-Oct. & $36-127$ & Quinn and Light (1989) \\
Bay of Fundy & $<100$ & Winter & $<0.18$ & Williams and Delbeek (1989) \\
New York Bright & $<110$ & May-July & $<2$ & Cowen and Chiarella (1991) \\
North Pacific Ocean, & $>22$ & ND & ND & Morita et al. (2009) \\
\hline Bering Sea, Okhotsk Sea & & & & \\
\hline
\end{tabular}

$N D$ not described

forms migrate to spawning sites in the coastal regions, their spawning sites overlap with those of the resident forms (Fig. 2b). Although the extent of gene flow between anadromous and resident forms varies according to the geography of the location, anadromous and resident forms are often reproductively isolated and genetically differentiated because of multiple isolating barriers, including eco- geographical isolation (Hagen 1967), temporal isolation (Hagen 1967), sexual isolation (Hay and McPhail 1975; McKinnon et al. 2004), and postzygotic isolation against hybrids (Jones et al. 2006, 2008).

Partial anadromous migration (i.e., part of a population migrates, while the other part does not) is also found in Japanese lakes. At least two lake populations, Lake 


\section{(a) Complete geographical isolation}

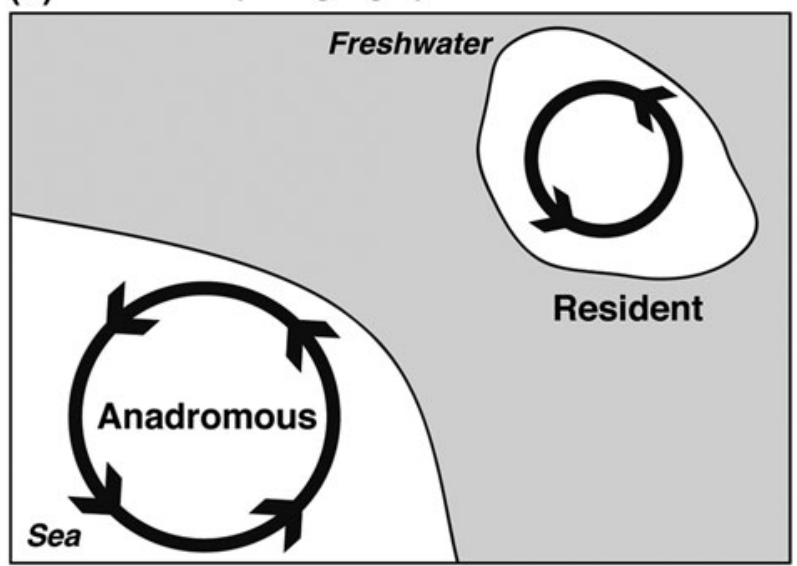

(b) Reproductive isolation with gene flow

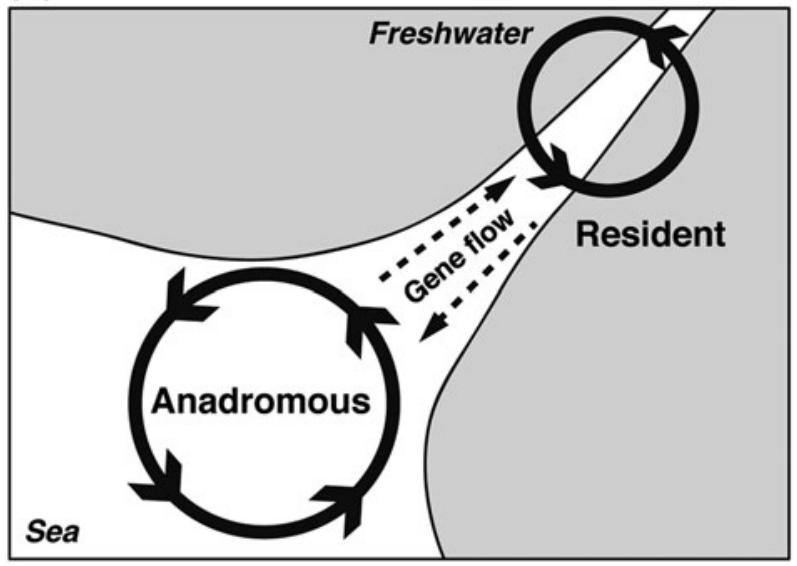

(c)

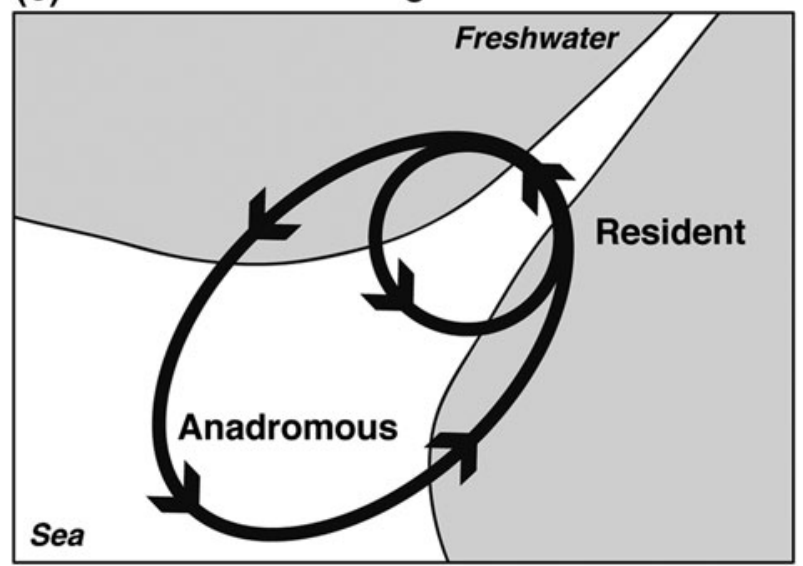

Fig. 2 a Complete geographical isolation between anadromous and resident forms. b Reproductive isolation with various levels of gene flow between anadromous and resident forms. c Polymorphism of anadromy and residency within a population

Harutori, and Lake Hyotan populations, exhibit polymorphism of anadromy and residency (Fig. 2c) (Mori 1990; Kitamura et al. 2006). No significant genetic differentiation in nuclear markers has been observed between the anadromous and resident forms in these two lakes (Higuchi et al. 1996; Kitano et al. 2007; Ishikawa and Kitano, unpublished data). Early growth rate may determine the migratory fate of each fish, as in the Atlantic salmon (Jones 1959; Hutchings and Myers 1994), because juvenile $G$. aculeatus descending a river are smaller than the juvenile G. aculeatus that remain in a pond (Kitamura et al. 2006). Populations that show partial migration are particularly suitable for investigating the genetic basis of migratory behavior, because such polymorphic populations maintain genetic variation in traits important for both migration and residency (Berthold 1993; Pulido 2011).

\section{Physiological basis for stickleback migration}

Several physiological and behavioral traits important for anadromous migration diverge between anadromous and resident forms (Table 4). Divergence in salinity preference may contribute to the divergence in migratory behaviors. Other traits related to migration, such as metabolic rate, swimming endurance, and osmoregulation, also diverge between anadromous and resident forms. The expression of these traits is regulated by hormones (Table 5). Thyroid hormone signaling pathways are one of the most extensively characterized systems that have been compared between anadromous and resident forms (Fig. 3). Anadromous forms have higher plasma thyroxine and triiodothyronine levels than resident forms (Kitano et al. 2010). Thyroid hormone increases the metabolic rate and swimming activity in Gasterosteus aculeatus (Gutz 1970; Kitano et al. 2010). Therefore, higher thyroid hormone levels may be adaptive for longer distance migration in anadromous forms; such migrations require more energy than that required by resident forms. Importantly, thyroid hormone not only regulates swimming activity (Kitano et al. 2010), but also salinity preference behavior (Baggerman 1957). Although thyroid hormones do not exhibit photoperiodic changes in either anadromous or resident forms, mRNA expression levels of the thyroid stimulating hormone- $\beta 2$ $(T S H \beta 2)$ in the pituitary gland exhibit striking photoperiodic changes only in anadromous forms (Kitano et al. 2010). Because TSH regulates the synthesis and release of thyroid hormones in thyroid gland, and the sensitivity of thyroid hormones in peripheral tissues (Wu et al. 1985), thyroid hormone signaling pathways may be an important regulator of migratory behavior in G. aculeatus.

The genetic basis for divergence in thyroid hormone signaling pathways between anadromous and resident forms has also been investigated. Pyrosequencing of $T S H \beta 2$ transcripts in hybrids between anadromous and resident forms revealed that divergence in the cis-regulatory regions of the TSH $\beta 2$ gene can partially explain the 

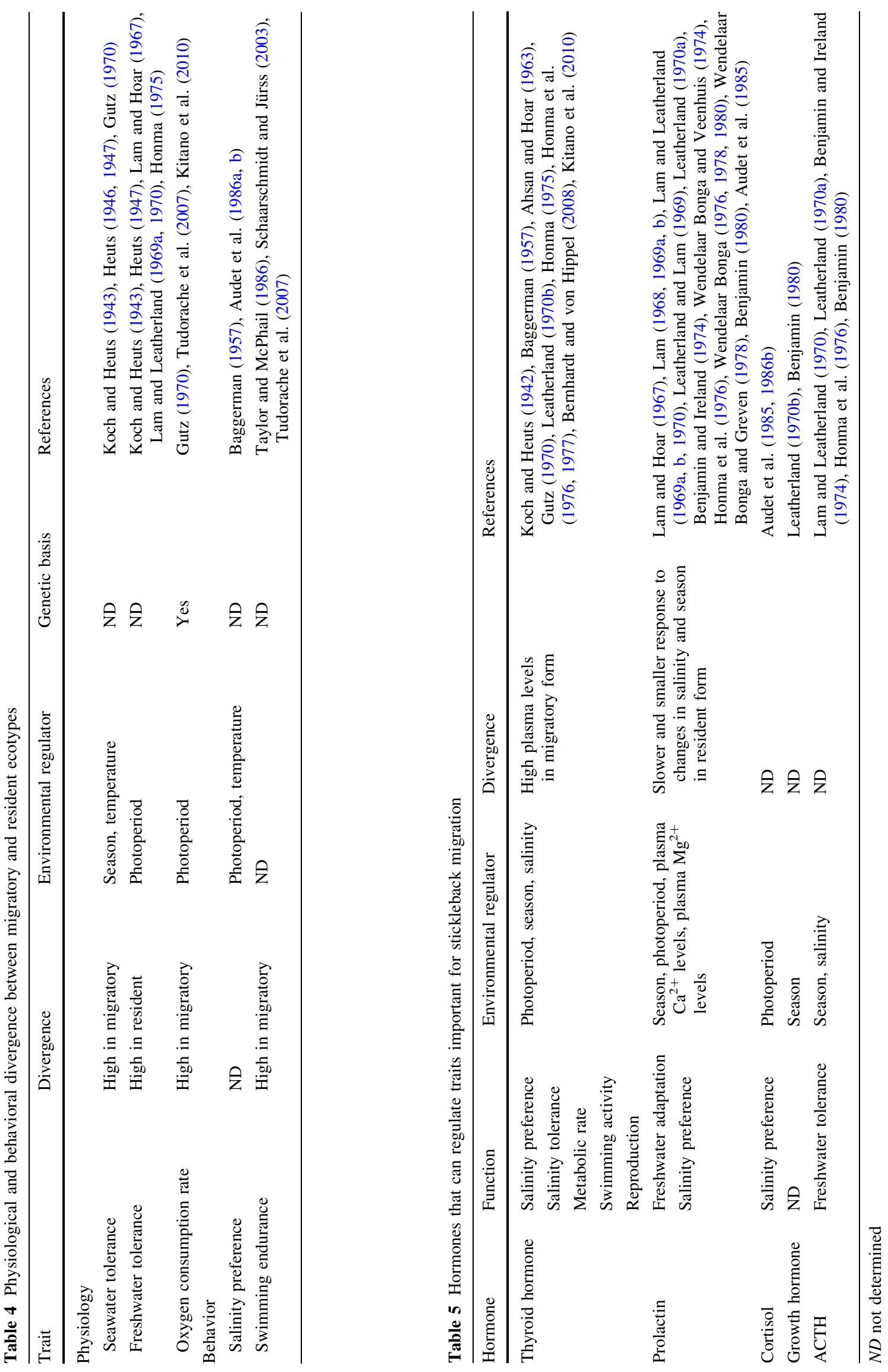


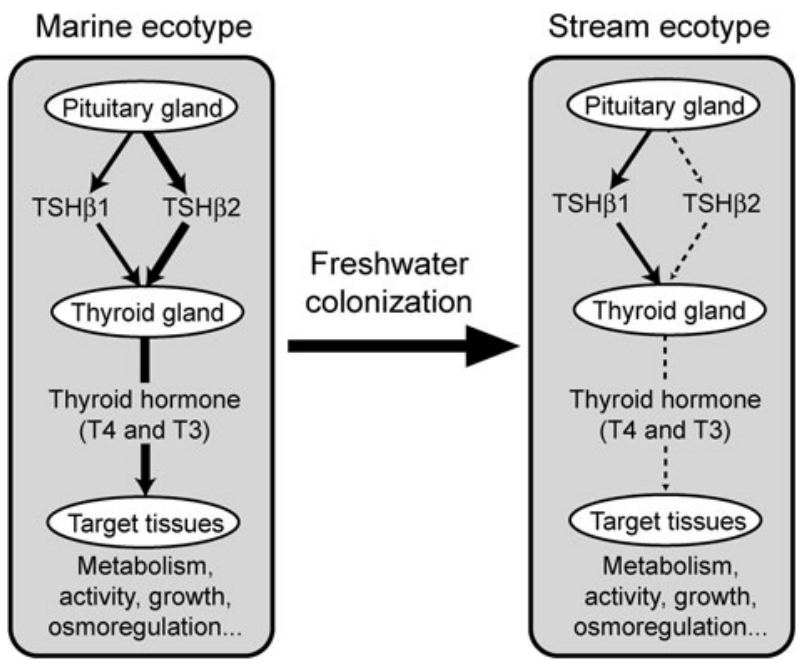

Fig. 3 Schema of thyroid hormone signaling pathways in anadromous and resident forms of three-spined sticklebacks

differential expression of TSH $\beta 2$ (Kitano et al. 2010). In addition, a signature of divergent selection was also observed at the TSH $\beta 2$ locus: most anadromous forms from multiple geographical regions have one type of allele, whereas most stream-resident forms have another type of allele (Kitano et al. 2010). A similar signature of divergent selection was observed at the ectodysplasin $(E d a)$ and the kit ligand (kitlg) genes, which are responsible for repeated evolution of the low-armored phenotype (Colosimo et al. 2005) and reduced pigmentation (Miller et al. 2007), respectively, in freshwater-resident forms of G. aculeatus. The TSH $\beta 2$, Eda, and kitlg genes are located on different chromosomes. Therefore, divergent natural selection acted on various chromosomal regions leading to parallel evolution of multiple phenotypic traits.

The signaling pathways of other hormones may also diverge between migratory and resident forms. For example, prolactin is important for freshwater adaptation; injections of prolactin increase the survival rate of anadromous forms in fresh water (Lam 1968; Lam and Leatherland 1969a, 1970). Prolactin regulates the osmotic influx of water in isolated gills (Lam 1969a) and structural changes in the kidney (Lam and Leatherland 1969b; Wendelaar Bonga and Veenhuis 1974; Wendelaar Bonga 1976) in anadromous forms. Other hormones, such as gonadal steroids, also play important roles in migration, such as in the migration of eels (Lokman et al. 1998; Lokman and Young 1998; Sudo et al. 2011) and salmonids (Munakata et al. 2001, 2002). However, divergence in the signalling pathways of prolactin or gonadal steroids between anadromous and freshwater-resident forms has not yet been characterized, but it should be investigated in the future.

\section{The future of physiological genomics of fish migration}

Studies on TSH $\beta 2$ demonstrate that the search for a genomic signature of divergent selection between different migratory forms will be useful for identifying the candidate genes important for divergence in migratory behaviors (Fig. 4a). By using microsatellite markers, divergent loci between anadromous and freshwater forms, including genes potentially important for physiological adaptation, have been identified (Mäkinen et al. 2008; DeFaveri et al. 2011; Shimada et al. 2011). Recent progress in next-generation sequencers is making it possible to find an increasing number of genetic markers at relatively low costs (Hudson 2008; Stapley et al. 2010; Davey et al. 2011; Elmer and Meyer 2011). For example, SNP analysis with sequenced RAD is a powerful method to identify a signature of divergent selection (Baird et al. 2008; Hohenlohe et al. 2010; Roesti et al. 2012). Because the genome sequences of Gasterosteus aculeatus are relatively small $(<450 \mathrm{Mb})$ and the reference genome sequence is available (Kingsley and Peichel 2007; Jones et al. 2012b), wholegenome re-sequencing of $G$. aculeatus is relatively easy by using next-generation sequencers (Jones et al. 2012b). The presence of multiple phylogenetically independent pairs of anadromous and freshwater-resident sticklebacks provide us great opportunities to scan the genome for regions that contribute to the repeated evolution of adaptive traits importance for freshwater residency (Jones et al. 2012a, b; Elmer and Meyer 2011).

Studies on TSH $\beta 2$ also demonstrate that transcriptome analysis will be useful in identifying genes potentially involved in the initial switch to migration (Fig. 4b). Transcriptomic studies of salmon migration have been extensively conducted (Aubin-Horth et al. 2005, 2009; Giger et al. 2006; Bernier et al. 2008; Miller et al. 2009, 2011; Seear et al. 2010). Microarrays of G. aculeatus, which have been used to investigate the effects of endocrine disruptors (Geoghegan et al. 2008; Williams et al. 2009; Katsiadakia et al. 2010), sex-biased gene expression (Leder et al. 2010), the transcriptomic response to predators (Sanogo et al. 2011), comparison of gill transcripts between anadromous and stream-resident forms (Kitano et al. 2010), and comparison of testis transcripts between incipient species (Kitano et al. 2011), are also useful for transcriptome analyses of divergent migratory forms of G. aculeatus at various migratory stages.

Quantitative trait loci (QTL) mapping, performed for Oncorhynchus mykiss (Walbaum 1792) (Nichols et al. 2008), is also useful in identifying the genomic regions responsible for divergence in behavioral traits and photoperiodic response between migratory and resident forms of G. aculeatus (Fig. 4c). Gasterosteus aculeatus is a suitable model system for QTL mapping because its body size, 
(a)

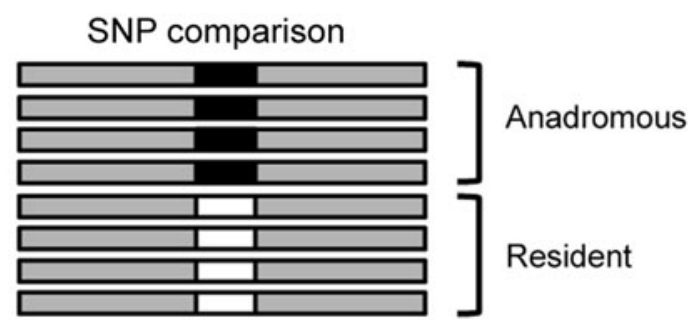

(b)

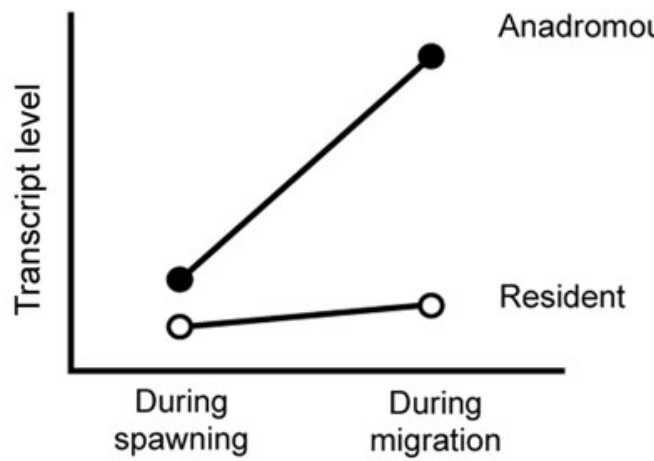

(c)

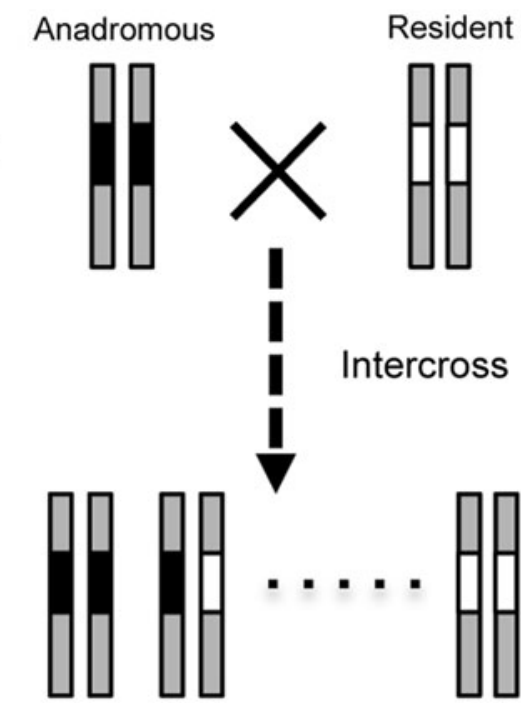

F2

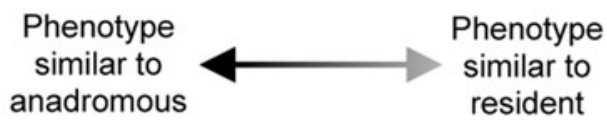

Fig. 4 Genomic studies of divergence in migratory behaviors. a Genome scan analysis can reveal chromosomal regions that repeatedly diverge between multiple anadromous and resident populations. b Transcriptome analysis can reveal genes that exhibit expression difference in accordance with seasonal migration in anadromous forms, but not in resident forms. c QTL mapping using an intercross between an anadromous form and a resident form can reveal chromosomal regions that explain phenotypic variation in traits important for seasonal migration

genome size, and generation time are smaller than those of salmonids. QTL mapping of several morphological and behavioral traits has been successfully performed for G. aculeatus (Peichel et al. 2001; Colosimo et al. 2004,
2005; Cresko et al. 2004; Shapiro et al. 2004; Albert et al. 2008; Kitano et al. 2009; Greenwood et al. 2011).

Finally, it should be noted that rapid advances in nextgeneration sequencers are making it possible to obtain a large amount of sequence data, even for non-model organisms (Hudson 2008; Stapley et al. 2010; Davey et al. 2011; Elmer and Meyer 2011). Therefore, the gap between model and non-model organisms is becoming increasingly blurred. Next-generation sequencers would facilitate genome scan analyses by using sequenced RAD (Baird et al. 2008; Hohenlohe et al. 2010; Rowe et al. 2011; Roesti et al. 2012) and transcriptome analyses by RNA-sequencing in non-model organisms (Vera et al. 2008). Applications of such genomic tools to non-model organisms that exhibit diverse migratory behaviors will enable us to elucidate whether the same sets of genes are important in the divergence of migratory behaviors across diverse taxa.

Acknowledgments This research was supported by JST PRESTO program, the Naito Foundation, NIG Collaborative Research Program (2011-A69), Grant-in-Aid for Young Scientist (B), and Grant-in-Aid for Scientific Research on Innovative Areas (23113007 and 23113001) from the Ministry of Education, Science, Sports and Culture to J.K. Japan Society for the Promotion of Science supported A.I. We thank B. R. Chapman (Lund University) for constructive comments on the manuscript and Ryu Uchiyama (photographer) and Yuichi Kano (Kyushu University) for help with taking stickleback photographs.

\section{References}

Ahsan SN, Hoar WS (1963) Some effects of gonadotropic hormones on the threespine stickleback, Gasterosteus aculeatus. Can J Zool 41:1045-1053

Albert AY, Sawaya S, Vines TH, Knecht AK, Miller CT, Summers BR, Balabhadra S, Kingsley DM, Schluter D (2008) The genetics of adaptive shape shift in stickleback: pleiotropy and effect size. Evolution 62:76-85

Amaoka K, Haruta C (1972) Threespine stickleback, Gasterosteus aculeatus aculeatus, new record from Shimonoseki. Jpn J Ichthyol 19:129-131

Aubin-Horth N, Landry CR, Letcher BH, Hofmann HA (2005) Alternative life histories shape brain gene expression profiles in males of the same population. Proc Roy Soc B 272:1655-1662

Aubin-Horth N, Letcher BH, Hofmann HA (2009) Gene-expression signatures of Atlantic salmon's plastic life cycle. Gen Comp Endocr 163:278-284

Audet C, FitzGerald GJ, Guderley H (1985) Salinity preferences of four sympatric sticklebacks (Gasterosteidae) during their reproductive season. Copeia 1985:209-213

Audet C, FitzGerald GJ, Guderley H (1986a) Environmental control of salinity preferences in four sympatric species of sticklebacks: Gasterosteus aculeatus, Gasterosteus wheatlandi, Pungitius pungitius and Apeltes quadracus. J Fish Biol 28:725-739

Audet C, FitzGerald GJ, Guderley H (1986b) Photoperiod effects on plasma cortisol levels in Gasterosteus aculeatus. Gen Comp Endocr 61:76-81

Baggerman B (1957) An experimental study on the timing of breeding and migration in the three-spined stickleback (Gasterosteus aculeatus L.). Arch Néerland Zool 12:105-317 
Baird NA, Etter PD, Atwood TS, Currey MC, Shiver AL, Lewis ZA, Selker EU, Cresko WA, Johnson EA (2008) Rapid SNP discovery and genetic mapping using sequenced RAD markers. PLoS ONE 3:e3376

Bell MA, Foster SA (1994) The evolutionary biology of the threespine stickleback. Oxford University Press, Oxford

Benjamin M (1980) The response of prolactin, ACTH, and growth hormone cells in the pituitary gland of the three-spined stickleback, Gasterosteus aculeatus L. form leiurus, to increased environmental salinities. Acta Zool Stockholm 61:1-7

Benjamin M, Ireland MP (1974) The ACTH-interrenal axis in the freshwater stickleback, Gasterosteus aculeatus form leiurus. Cell Tissue Res 155:105-115

Bernhardt RR, von Hippel FA (2008) Chronic perchlorate exposure impairs stickleback reproductive behaviour and swimming performance. Behaviour 145:527-559

Bernier JC, Birkeland SR, Cipriano MJ, McArthur AG, Banks MA (2008) Differential gene expression between fall- and spring-run Chinook salmon assessed by long serial analysis of gene expression. Trans Am Fish Soc 137:1378-1388

Berthold P (1993) Bird migration. Oxford University Press, Oxford

Candolin U, Voigt H-R (2003) Size-dependent selection on arrival times in sticklebacks: why small males arrive first. Evolution 57:862-871

Chan YF, Marks ME, Jones FC, Villarreal G Jr, Shapiro MD, Brady SD, Southwick AM, Absher DM, Grimwood J, Schmutz J, Myers RM, Petrov D, Jonsson B, Schluter D, Bell MA, Kingsley DM (2010) Adaptive evolution of pelvic reduction in sticklebacks by recurrent deletion of a Pitx 1 enhancer. Science 32:302-305

Chapman BR, Brönmark C, Nilsson J-A, Hansson L-A (2011) The ecology and evolution of partial migration. Oikos 120:1764-1775

Colosimo PF, Peichel CL, Nereng K, Blackman BK, Shapiro MD, Schluter D, Kingsley DM (2004) The genetic architecture of parallel armor plate reduction in threespine sticklebacks. PLoS Biol 2:e109

Colosimo PF, Hosemann KE, Balabhadra S, Villarreal G Jr, Dickson M, Grimwood J, Schmutz J, Myers RM, Schluter D, Kingsley DM (2005) Widespread parallel evolution in sticklebacks by repeated fixation of Ectodysplasin alleles. Science 307:1928-1933

Cowen RK, Chiarella LA (1991) Offshore distribution, size, age, and lateral plate variation of late larval/early juvenile sticklebacks (Gasterosteus) off the Atlantic coast of New Jersey and New York. Can J Fish Aquat Sci 48:1679-1684

Craig-Bennett A (1931) The reproductive cycle of the three-spined stickleback, Gasterosteus aculeatus L. Philos Trans R Soc London 219:197-279

Cresko WA, Amores A, Wilson C, Murphy J, Currey M, Phillips P, Bell MA, Kimmel CB, Postlethwait JH (2004) Parallel genetic basis for repeated evolution of armor loss in Alaskan threespine stickleback populations. Proc Natl Acad Sci USA 101:6050-6055

Cresko WA, McGuigan KL, Phillips PC, Postlethwait JH (2006) Studies of threespine stickleback developmental evolution: progress and promise. Genetica 129:105-126

Davey JW, Hohenlohe PA, Etter PD, Boone JQ, Catchen JM, Blaxter ML (2011) Genome-wide genetic marker discovery and genotyping using next-generation sequencing. Nature Genet 12:499-510

DeFaveri J, Shikano T, Shimada Y, Goto A, Merilä J (2011) Global analysis of genes involved in freshwater adaptation in threespine sticklebacks (Gasterosteus aculeatus). Evolution 65:1800-1807

Dodson JJ (1997) Fish migration: an evolutionary perspective. In: Godin J-G (ed) Behavioural Ecology of Teleost Fishes. Oxford University Press, Oxford, pp 10-36

Elmer ER, Meyer A (2011) Adaptation in the age of ecological genomics: insights from parallelism and convergence. Trends Ecol Evol 26:298-306
Geoghegan F, Katsiadaki I, Williams TD, Chipman JK (2008) A cDNA microarray for the three-spined stickleback, Gasterosteus aculeatus L., and analysis of the interactive effects of oestradiol and dibenzanthracene exposures. J Fish Biol $72: 2133-2153$

Giger T, Excoffier L, Day PJR, Champigneulle A, Hansen MM, Powell R, Largiadèr CR (2006) Life history shapes gene expression in salmonids. Curr Biol 16:R281-R282

Greenwood AK, Jones FC, Chan YF, Brady SD, Absher DM, Grimwood J, Schmutz J, Myers RM, Kingsley DM, Peichel CL (2011) The genetic basis of divergent pigment patterns in juvenile threespine sticklebacks. Heredity 107:155-166

Gross MR (1985) Disruptive selection for alternative life histories in salmon. Nature 313:47-48

Gross MR (1997) Evolution of life history and migration in fish. Mem Fac Fish Hokkaido Univ 44:1-5

Gross MR, Coleman RM, McDowall RM (1988) Aquatic productivity and the evolution of diadromous fish migration. Science 239:1291-1293

Gutz M (1970) Experimentelle Untersuchungen zur Salzadaptation verschiedener Rassen des Dreistachligen Stichlings (Gasterosteus aculeatus L.). Int Rev Hydrobiol 55:845-894

Hagen DW (1967) Isolating mechanisms in threespine sticklebacks (Gasterosteus). J Fish Res Board Can 24:1637-1692

Haglund TR, Buth DG, Lawson R (1992) Allozyme variation and phylogenetic relationships of Asian, North American, and European populations of the threespine stickleback, Gasterosteus aculeatus. Copeia 1992:432-443

Hay DE, McPhail JD (1975) Mate selection in threespine sticklebacks (Gasteroteus). Can J Zool 53:441-450

Hendry AP, Stearns SC (2004) Evolution illuminated. Oxford University Press, Oxford

Hensleigh JE, Hendry AP (1998) Rheotactic response of fry from beach-spawning populations of sockeye salmon: evolution after selection is relaxed. Can J Zool 76:2186-2193

Heuts MJ (1946) Physiological isolating mechanisms and selection within the species Gasterosteus aculeatus L. Nature 158:839-840

Heuts MJ (1947) Experimental studies of adaptive evolution in Gasterosteus aculeatus L. Evolution 1:89-102

Higuchi M, Goto A, Yamazaki F (1996) Genetic structure of threespine stickleback, Gasterosteus aculeatus, in Lake Harutori, Japan, with reference to coexisting anadromous and freshwater forms. Ichthyol Res 43:349-358

Hoar WS (1958) The evolution of migratory behaviour among juvenile salmon of the genus Oncorhynchus. J Fish Res Board Can 15:391-428

Hoar WS (1976) Smolt transformation: evolution, behaviour, and physiology. J Fish Res Board Can 33:1233-1252

Hoar WS, Keenleyside MHA, Goodall RG (1957) Reactions of juvenile Pacific salmon to light. J Fish Res Board Can 14:815-830

Hohenlohe PA, Bassham S, Etter PD, Stiffler N, Johnson EA, Cresko WA (2010) Population genomics of parallel adaptation in threespine stickleback using sequenced RAD tags. PLoS Genet 6:e1000862

Honma Y (1975) Excessively enlarged thyroid follicles of the threespine stickleback, Gasterosteus aculeatus reared in freshwater. Jpn J Ichthyol 21:183-190

Honma Y, Teshigawara H, Chiba A (1976) Changes in the cells of the adenohypophysis associated with the diadromous migration of the threespine stickleback, Gasterosteus aculeatus L. Arch Histol Jpn 39:1-14

Honma Y, Shioda S, Yoshie S (1977) Changes in the thyroid gland associated with the diadromous migration of the threespine stickleback, Gasterosteus aculeatus. Jpn J Ichthyol 24:17-25 
Hosemann KE, Colosimo PF, Summers BR, Kingsley DM (2004) A simple and efficient microinjection protocol for making transgenic sticklebacks. Behaviour 141:1345-1355

Houston AH (1957) Responses of juvenile chum, pink, and Coho salmon to sharp sea-water gradients. Can J Zool 35:371-383

Hudson ME (2008) Sequencing breakthroughs for genomic ecology and evolutionary biology. Mol Ecol 8:3-17

Hutchings JA, Myers RA (1994) The evolution of alternative mating strategies in variable environments. Evol Ecol 8:256-268

Hutchinson MJ, Iwata M (1997) A comparative analysis of aggression in migratory and non-migratory salmonids. Environ Biol Fish 50:209-215

Ikeda K (1937) Effect of castration on the secondary sexual characters of anadromous three-spined stickleback, Gasterosteus aculeatus (L.). Jpn J Zool 44:137-157

Iwata M (1995) Downstream migratory behavior of salmonids and its relationship with cortisol and thyroid hormones: a review. Aquaculture 135:131-139

Iwata M, Ogura H, Komatsu S, Suzuki K (1986) Loss of seawater preference in chum salmon (Oncorhynchus keta) fry reared in fresh water after migration season. J Exp Zool 240:369-376

Jones JW (1959) The salmon. Collins, London

Jones DH, John AWG (1978) A three-spined stickleback, Gasterosteus aculeatus L. from the North Atlantic. J Fish Biol 13:231-236

Jones FC, Brown C, Pemberton JM, Braithwaite VA (2006) Reproductive isolation in a threespine stickleback hybrid zone. J Evol Biol 19:1531-1544

Jones FC, Brown C, Braithwaite VA (2008) Lack of assortative mating between incipient species of stickleback from a hybrid zone. Behaviour 145:463-484

Jones FC, Chan YF, Schmutz J, Grimwood J, Brady SD, Southwick AM, Absher DM, Myers RM, Reimchen TE, Deagle BE, Schluter D, Kingsley DM (2012a) A genome-wide SNP genotyping array reveals patterns of global and repeated species-pair divergence in sticklebacks. Curr Biol 22:83-90

Jones FC, Grabherr MG, Chan YF, Russell P, Mauceli E, Johnson J, Swofford R, Pirun M, Zody MC, White S, Birney E, Searle S, Schmutz J, Grimwood J, Dickson MC, Myers RM, Miller CT, Summers BR, Knecht AK, Brady SD, Zhang H, Pollen AA, Howes $\mathrm{T}$, Amemiya C, Broad Institute Genome Sequencing Platform \& Whole Genome Assembly Team, Lander ES, Di Palma F, Lindblad-Toh K, Kingsley DM (2012b) The genomic basis of adaptive evolution in threespine sticklebacks. Nature 484:55-61

Katayama S, Hino Y, lizuka K (2000) Life history of the threespine stickleback, Gasterosteus aculeatus (L.), in Lake Ogawara, Japan. Bull Jpn Soc Fish Oceanor 64:209-214

Katsiadakia I, Williamsb TD, Ballc JS, Beana TP, Sandersa MB, Wub H, Santosc EM, Brownd MM, Bakerd P, Ortegab F, Falcianib F, Craftd JA, Tylerc CR, Viantb MR, Chipmanb JK (2010) Hepatic transcriptomic and metabolomic responses in the stickleback (Gasterosteus aculeatus) exposed to ethinyl-estradiol. Aquat Toxicol 97:174-187

Kemp PS, Gessel MH, Williams JG (2005) Seaward migrating subyearling Chinook salmon avoid overhead cover. J Fish Biol 67:1381-1391

Kingsley DM, Peichel CL (2007) The molecular genetics of evolutionary changes in sticklebacks. In: Mayer I, Huntingford FA, Östlund-Nilsson S (eds) Biology of the three-spined stickleback. CRC Press, Boca Raton, pp 41-81

Kitamura T, Kume M, Takahashi H, Goto A (2006) Juvenile bimodal length distribution and sea-run migration of the lower modal group in the Pacific Ocean form of three-spined stickleback. J Fish Biol 69:1245-1250

Kitano J, Mori S, Peichel CL (2007) Phenotypic divergence and reproductive isolation between sympatric forms of Japanese threespine sticklebacks. Biol J Linn Soc 91:671-685
Kitano J, Ross JA, Mori S, Kume M, Jones FC, Chan YF, Absher DM, Grimwood J, Schmutz J, Myers RM, Kingsley DM, Peichel CL (2009) A role for a neo-sex chromosome in stickleback speciation. Nature 461:1079-1083

Kitano J, Lema SC, Luckenbach JA, Mori S, Kawagishi Y, Kusakabe M, Swanson P, Peichel CL (2010) Adaptive divergence in the thyroid hormone signaling pathway in the stickleback radiation. Curr Biol 20:2124-2130

Kitano J, Kawagishi Y, Mori S, Peichel CL, Makino T, Kawata M, Kusakabe M (2011) Divergence in sex steroid hormone signaling between sympatric species of Japanese threespine stickleback. PLoS ONE 6:e29253

Koch J, Heuts MJ (1942) Influence de l'hormone thyroidienne sur la régulation osmotique chez Gasterosteus aculeatus L. forme gymmurus. Annal Soc Roy Zool Belgique 73:165-172

Koch HJ, Heuts MJ (1943) Régulation osmotique, cycle sexuel et migration de reproduction chez les épinoches. Arch Int Physiol 53:253-266

Kume M (2008) Japan Sea form of threespine stickleback, Gasterosteus aculeatus, from the Isumi and Kuriyama Rivers in Chiba Prefecture: possibility of the southernmost population. Biol Inland Water 23:21-26

Kume M, Kitamura T (2003) Breeding ecology and reproductive isolation of two genetic forms of threespine stickleback in sympatry. In: Goto A, Mori S (eds) Natural history of sticklebacks. Hokkaido University Press, Sapporo, pp 144-153

Kume M, Mori S (2009) Sea-run migratory behaviour in the Japan Sea form of three-spined stickleback Gasterosteus aculeatus in the tidal pool of eastern Hokkaido Island, Japan. J Fish Biol 75:2845-2850

Kume M, Kitamura T, Takahashi H, Goto A (2005) Distinct spawning migration patterns in sympatric Japan Sea and Pacific Ocean forms of threespine stickleback Gasterosteus aculeatus. Ichthyol Res 52:189-193

Lam TJ (1968) Effect of prolactin on plasma electrocytes of the earlywinter marine threespine stickleback, Gasterosteus aculeatus, form trachurus, following transfer from sea- to fresh water. Can J Zool 46:1095-1097

Lam TJ (1969a) The effect of prolactin on osmotic influx of water in isolated gills of the marine threespine stickleback Gasterosteus aculeatus L., form trachurus. Comp Biochem Phys 31:909-913

Lam TJ (1969b) Effects of prolactin on loss of solutes via the head region of the early-winter marine threespine stickleback (Gasterosteus aculeatus L., form trachurus) in fresh water. Can J Zool 47:865-869

Lam TJ, Hoar WS (1967) Seasonal effects of prolactin on freshwater osmoregulation of the marine form (trachurus) of the stickleback Gasterosteus aculeatus. Can J Zool 45:509-516

Lam TJ, Leatherland JF (1969a) Effect of prolactin on freshwater survival of the marine form (trachurus) of the threespine stickleback, Gasterosteus aculeatus, in the early winter. Gen Comp Endocr 12:385-394

Lam TJ, Leatherland JF (1969b) Effects of prolactin of the glomerulus of the marine threespine stickleback, Gasterosteus aculeatus L., form trachurus, after transfer from seawater to fresh water, during the late autumn and early winter. Can J Zool 47:245-250

Lam TJ, Leatherland JF (1970) Effect of hormones on survival of the marine form (trachurus) of the threespine stickleback (Gasterosteus aculeatus L.) in deionized water. Comp Biochem Phys 33:295-302

Leatherland JF (1970a) Seasonal variation in the structure and ultrastructure of the pituitary of the marine form (trachurus) of the threespine stickleback, Gasterosteus aculeatus L. I. Rostral pars distalis. Z Zellfor 104:301-317

Leatherland JF (1970b) Seasonal variation in the structure and ultrastructure of the pituitary of the marine form (trachurus) of 
the threespine stickleback, Gasterosteus aculeatus L. II. Proximal pars distalis and neuro-intermediate lobe. Z Zellfor 104:318-336

Leatherland JF, Lam TJ (1969) Prolactin and survival in deionized water of the marine form (trachurus) of the threespine stickleback, Gasterosteus aculeatus L. Can J Zool 47:989-995

Leder EH, Merilä J, Primmer CR (2009) A flexible whole-genome microarray for transcriptomics in three-spine stickleback (Gasterosteus aculeatus). BMC Genomics 10:428

Leder EH, Cano JM, Leinonen T, O'Hara RB, Nikinmaa M, Primmer CR, Merilä J (2010) Female-biased expression on the $X$ chromosome as a key step in sex chromosome evolution in threespine sticklebacks. Mol Biol Evol 27:1495-1503

Leiner M (1930) Fortsetzung der Okologischen Studien an Gasterosteus aculeatus. Z Morphol Okol Tiere 14:360-399

Lokman PM, Young G (1998) Gonad histology and plasma steroid profiles in wild New Zealand freshwater eels (Anguilla dieffenbachii and A. australis) before and at the onset of the natural spawning migration. II. Males. Fish Phys Biochem 19:339-347

Lokman PM, Vermeulen GJ, Lambert JGD, Young G (1998) Gonad histology and plasma steroid profiles in wild New Zealand freshwater eels (Anguilla dieffenbachii and A. australis) before and at the onset of the natural spawning migration. I. Females. Fish Phys Biochem 19:325-338

Mäkinen HS, Shikano T, Cano JM, Merilä J (2008) Hitchhiking mapping reveals a candidate genomic region for natural selection in three-spines stickleback chromosome VIII. Genetics 178:3565-3582

McCormick SD (2001) Endocrine control of osmoregulation in teleost fish. Am Zool 41:781-794

McDowall RM (1988) Diadromy in fishes. Croom Helm, London

McInerney JE (1964) Salinity preference: an orientation mechanism in salmon migration. J Fish Res Board Can 21:995-1018

McKeown BA (1984) Fish Migration. Croom Helm, Sydney

McKinnon JS, Rundle HD (2002) Speciation in nature: the threespine stickleback model systems. Trends Ecol Evol 17:480-488

McKinnon JS, Mori S, Blackman BK, David L, Kingsley DM, Jamieson L, Chou J, Schluter D (2004) Evidence for ecology's role in speciation. Nature 429:294-298

Miller CT, Beleza S, Pollen AA, Schluter D, Kittles RA, Shriver MD, Kingsley DM (2007) cis-Regulatory changes in Kit ligand expression and parallel evolution of pigmentation in sticklebacks and humans. Cell 131:1179-1189

Miller KM, Schulze AD, Ginthera N, Lia S, Patterson DA, Farrell AP, Hinch SG (2009) Salmon spawning migration: Metabolic shifts and environmental triggers. Comp Biochem Phys D 4:75-89

Miller KM, Li S, Kaukinen KH, Ginther N, Hammill E, Curtis JMR, Patterson DA, Sierocinski T, Donnison L, Pavlidis P, Hinch SG, Hruska KA, Cooke SJ, English KK, Farrell AP (2011) Genomic signatures predict migration and spawning failure in wild Canadian salmon. Science 331:214-217

Mori S (1987) Divergence in reproductive ecology of the three-spined stickleback, Gasterosteus aculeatus. Jpn J Icthyol 34:165-175

Mori S (1990) Two morphological types in the reproductive stock of three-spined stickleback, Gasterosteus aculeatus, in Lake Harutori, Hokkaido Island. Environ Biol Fish 27:21-31

Morita K, Morita SH, Fukuwara M (2009) Offshore distributions of anadromous lamprey and threespine stickleback. In North Pacific Anadromous Fish Commission, pp 1-4

Munakata A, Amano M, Ikuta K, Kitamura S, Aida K (2001) The Effects of Testosterone on Upstream Migratory Behavior in Masu Salmon, Oncorhynchus masou. Gen Comp Endocr 122:329-340

Munakata A, Amano M, Ikuta K, Kitamura S, Aida K (2002) Sex steroids control migration of masu salmon. Fish Sci 68:49-52
Nichols KM, Edo AF, Wheeler PA, Thorgaard GH (2008) The genetic basis of smoltification-related traits in Oncorhynchus mykiss. Genetics 179:1559-1575

Orti G, Bell MA, Reimchen TE, Meyer A (1994) Global survey of mitochondrial DNA sequences in the threespine stickleback: evidence for recent migrations. Evolution 48:608-622

Östlund-Nilsson S, Mayer I, Huntingford FA (2007) Biology of the three-spined stickleback. CRC Press, Boca Raton

Peichel CL (2005) Fishing for the secrets of vertebrate evolution in threespine sticklebacks. Dev Dyn 234:815-823

Peichel CL, Nereng KS, Ohgi KA, Cole BL, Colosimo PF, Buerkle CA, Schluter D, Kingsley DM (2001) The genetic architecture of divergence between threespine stickleback species. Nature 414:901-905

Pulido F (2011) Evolutionary genetics of partial migration - the threshold model of migration revis(it)ed. Oikos 120:1776-1783

Quinn TP (2005) The behavior and ecology of Pacific salmon and trout. University of Washington Press, Seattle

Quinn TP, Light JT (1989) Occurrence of threespine stickleback (Gasterosteus aculeatus) in the open North Pacific Ocean: migration or drift? Can J Zool 67:2850-2852

Ramenofsky M, Wingfield JC (2007) Regulation of migration. BioScience 57:135-143

Roesti M, Hendry AP, Salzburger W, Berner D (2012) Genome divergence during evolutionary diversification as revealed in replicate lake-stream stickleback population pairs. Mol Ecol (in press)

Rowe HC, Renaut S, Guggisberg A (2011) RAD in the realm of nextgeneration sequencing technologies. Mol Ecol 20:3499-3502

Sanogo YO, Hankison S, Band M, Obregon A, Bell AM (2011) Brain transcriptomic response of threespine sticklebacks to cues of a predator. Brain Behav Evol 77:270-285

Schaarschmidt T, Jürss K (2003) Locomotory capacity of Baltic Sea and freshwater populations of the threespine stickleback (Gasterosteus aculeatus). Comp Biochem Phys A 135:411-424

Seear PJ, Carmichael SN, Talbot R, Taggart JB, Bron JE, Sweeney GE (2010) Differential gene expression during smoltification of Atlantic salmon (Salmo salar L.): a first large-scale microarray study. Marine Biotech 12:126-140

Shapiro MD, Marks ME, Peichel CL, Blackman BK, Nereng KS, Jonsson B, Schluter D, Kingsley DM (2004) Genetic and developmental basis of evolutionary pelvic reduction in threespine sticklebacks. Nature 428:717-723

Shimada Y, Shikano T, Merilä J (2011) A high incidence of selection on physiologically important genes in the three-spined stickleback (Gasterosteus aculeatus). Mol Biol Evol 28:181-193

Snyder RJ, Dingle H (1989) Adaptive, genetically based differences in life history between estuary and freshwater threespine sticklebacks (Gasterosteus aculeatus L.). Can J Zool 67:2448-2454

Stapley J, Reger J, Feulner PGD, Smadja C, Galindo J, Ekblom R, Bennison C, Ball AD, Beckerman AP, Slate J (2010) Adaptation genomics: the next generation. Trends Ecol Evol 25:705-712

Sudo R, Suetake H, Suzuki Y, Utoh T, Tanaka S, Aoyama J, Tsukamoto K (2011) Dynamics of reproductive hormones during downstream migration in females of the Japanese eel, Anguilla japonica. Zool Sci 28:180-188

Taylor EB, McPhail JD (1985) Variation in burst and prolonged swimming performance among British Columbia populations of Coho salmon, Oncorhynchus kisutch. Can J Fish Aquat Sci 42:2029-2033

Taylor EB, McPhail JD (1986) Prolonged and burst swimming in anadromous and freshwater threespine stickleback, Gasterosteus aculeatus. Can J Zool 64:416-420

Taylor EB, McPhail JD (1999) Evolutionary history of an adaptive radiation in species pairs of threespine sticklebacks 
(Gasterosteus): insights from mitochondrial DNA. Biol J Linn Soc 66:271-291

Taylor EB, McPhail JD (2000) Historical contingency and ecological determinism interact to prime speciation in sticklebacks, Gasterosteus. Proc Roy Soc B 267:2375-2384

Tudorache C, Blust R, de Boeck G (2007) Swimming capacity and energetics of migrating and non-migrating morphs of threespined stickleback Gasterosteus aculeatus L. and their ecological implications. J Fish Biol 71:1448-1456

van Mullen PJ, van der Vlugt JC (1964) On the age, growth and migration of the anadromous stickleback Gasterosteus aculeatus L. investigated in mixed populations. Arch Neerland de Zool 16:111-138

Vera JC, Wheat CW, Fescemyer HW, Frilander MJ, Crawford DL, Hanski I, Marden JH (2008) Rapid transcriptome characterization for a nonmodel organism using 454 pyrosequencing. Mol Ecol 17:1636-1647

Wendelaar Bonga SE (1976) The effect of prolactin on kidney structure of the euryhaline teleost Gasterosteus aculeatus during adaptation to fresh water. Cell Tissue Res 66:319-338

Wendelaar Bonga SE (1978) The effects of changes in external sodium, calcium and magnesium concentrations on prolactin cells, and plasma electrolytes of Gasterosteus aculeatus. Gen Comp Endocr 34:265-275

Wendelaar Bonga SE (1980) Effect of synthetic salmon calcitonin and low ambient calcium on plasma calcium, ultimobranchial cells, Stannius bodies, and prolactin cells in the teleost, Gasterosteus aculeatus. Gen Comp Endocr 40:99-108
Wendelaar Bonga SE, Greven JAA (1978) The relationship between prolactin cell activity, environmental calcium, and plasma calcium in the teleost Gasterosteus aculeatus: observations on stanniectomized fish. Gen Comp Endocr 36:90-101

Wendelaar Bonga SE, Veenhuis M (1974) The effect of prolactin on the number of membrane-associated particles in kidney cells of the euryhaline teleost Gasterosteus aculeatus during transfer from seawater to freshwater: a freeze-etch study. J Cell Sci 16:687-701

Williams DD, Delbeek C (1989) Biology of the threespine stickleback, Gasterosteus aculeatus, and the blackspotted stickleback, Gasterosteus wheatlandi, during their marine pelagic phase in the Bay of Fundy, Canada. Environ Biol Fish 24:33-41

Williams TD, Wu H, Santos EM, Ball J, Katsiadaki I, Brown MM, Baker P, Ortega F, Falciani F, Craft JA, Tyler CR, Chipman JK, Viant MR (2009) Hepatic transcriptomic and metabolomic responses in the stickleback (Gasterosteus aculeatus) exposed to environmentally relevant concentrations of dibenzanthracene. Environ Sci Technol 43:6341-6348

Wootton RJ (1976) The biology of sticklebacks. Academic Press, London

Wootton RJ (1984) A Functional Biology of Sticklebacks. Croom Helm, London

Wu SY, Reggio R, Florsheim WH (1985) Characterization of thyrotropin-induced increase in iodothyronine monodeiodinating activity in mice. Endocrinology 116:901-908 